\title{
Peer to Peer Lending Against Ease of Business Technology Acceptance Model (TAM) Approach
}

\author{
Cita Sary Dja'akum \\ Universitas Islam Negeri Walisongo Semarang, Semarang, Indonesia \\ email: citasary@walisongo.ac.id
}

\begin{abstract}
The progress of the times will always go hand in hand with technological developments. The presence of the disruptive era encouraged the financial industry to innovate. Peer to Peer Lending (P2P Lending) is an online digital platform based alternative lending, which brings together lenders (investors) and borrowers in the marketplace. This study aims to see whether the presence of P2P Lending provides business convenience for lenders with reference to user satisfaction. The approach taken by using the Technology Acceptance Model (TAM) with Structural Equation Modeling (SEM). The results show that all variables consisting of User Perception directly influence Ease and Attitude Perception, Ease Perception directly influences Attitude and Satisfaction; and Perception of Use has an indirect effect on satisfaction with quasy mediation. Therefore, 55\% of respondents stated that P2P Lending provides convenience in doing business.
\end{abstract}

Keywords: Peer to Peer Lending; Fintech; TAM; SEM; Business Convenience

\begin{abstract}
Abstrak: Kemajuan jaman akan selalu beriringan dengan perkembangan teknologi. Hadirnya disruptive era mendorong industri keuangan untuk melakukan inovasi. Peer to Peer Lending (P2P Lending) merupakan alternatif digital lending berbasis platform online, yang mempertemukan lender (investor) dan borrower dalam market place. Penelitian ini bertujuan untuk melihat apakah hadirnya P2P Lending memberikan kemudahan bisnis bagi Lender dengan referensi kepuasan pengguna. Pendekatan yang dilakukan dengan menggunakan Technologi Acceptance Model (TAM) dengan Structural Equation Modelling (SEM). Hasil menunjukkan bahwa seluruh variabel yang terdiri dari Persepsi Pengguna berpengaruh langsung terhadap Persepsi Kemudahan dan Sikap, Persepsi Kemudahan berpengaruh langsung terhadap Sikap dan Kepuasan; serta Persepsi Penggunaan berpengaruh tidak langsung terhadap Kepuasan dengan sifat quasy mediation. Olah karenanya, 55\% responden menyatakan bahwa P2P Lending memberikan kemudahan dalam berbisnis.
\end{abstract}

Kata Kunci: Pinjaman Peer to Peer; Fintech; TAM; SEM; Kenyamanan Bisnis 
Cita Sary Dja'akum

\section{Introduction}

Technological development is something that cannot be avoided in today's life, because technological progress will go hand in hand with the progress of science (knowledge). Innovations are created to provide positive benefits and convenience for human life. Technology also gave rise to a new culture that was revolutionary. Humans today have enjoyed the many benefits brought about by technological innovations that have been created in the last decade. Especially in the current era of globalization, mastery of technology is a prestige and an indicator of a country's progress. A country is said to be advanced if it has a high level of technological mastery (high technology).

The development of technology inevitably affected the development of the financial industry (Nam et al., 2016). In the financial industry then emerged Financial Technology or often referred to as FinTech. After being introduced since 2015, FinTech has a positive trend in its development. The number of FinTech in Indonesia up to 2016 reached 142 companies with transaction value throughout 2016 of 199 trillion rupiah. The rapid development of FinTech is a concern for Bank Indonesia and the Financial Services Authority (OJK). Therefore, state policies through BI and OJK form various regulations such as rules regarding the Peer to Peer Lending (P2P Lending) business which was released on December 29, 2016.

The rapid development of FinTech is because of its ability to be an alternative transaction in facilitating the public to access financial products. Some types of FinTech that are developing in Indonesia are payment, lending, financial planning, retail investment, crowd funding, remittance, and financial research companies.

One of FinTech's products is Peer to Peer Lending (P2P Lending). P2P Lending is a technology platform that digitally meets borrowers who need venture capital with lenders who expect competitive returns. P2P Lending has the unique advantage of being able to perform interface functions through off- 
balance sheet funding. P2P Lending services are also more flexible and can allocate capital or funds to almost anyone, in any amount of value, effectively and transparently, with low interest.

Reynold Wijaya as the Coordinator of the P2P Lending Task Force of the FinTech Indonesia Association in FinTech Talk said that financial services such as P2P Lending are very relevant and are a breath of fresh air for Indonesians who are still working hard to complete a number of homework. According to him, first, Indonesia still needs to improve the level of financial inclusion of its people. The FinTech Association of Indonesia reports that there are still 49 million SMEs that have not been bankable in Indonesia, which is generally caused by business capital loans requiring collateral. P2P Lending can bridge credit worthy SMEs to become bankable by providing loans without collateral. Second, Indonesia must deal with uneven availability of financing services. In Indonesia, $60 \%$ of financing services are still concentrated in Java. By using technology, P2P Lending is able to reach almost anyone, anywhere, effectively and efficiently. Third, there is a development financing gap of $\mathrm{Rp} 1,000$ trillion every year. At present the existing financial institutions are only able to absorb the needs of around 700 trillion rupiah of the total needs of 1,700 rupiah trillion annually. P2P Lending offers low overhead, with credit scoring and an innovative algorithm to be able to fill the large needs of these financing. These potentials indicate that P2P Lending is actually the essence of financial inclusion that is able to open new segments of the economy, especially to the layers of Indonesian society that are not yet reached by existing financial institutions.

The growth and development of P2P Lending rapidly, indicating better user satisfaction of the lender and the borrower. This means that the presence of P2P Lending provides practical benefits for service users. Davis suggests that satisfaction will impact on intention to use (Davis, Jr., 1986). User satisfaction is created from the ease, usability, and attitude of users on P2P Lending products. The rapid development of FinTech is because users feel that

Economica: Jurnal Ekonomi Islam - Volume 10, Nomor 2 (2019) 
FinTech products make it easy for them to solve financial problems. This research is concerned to further examine whether P2P Lending has an impact on the ease of doing business for service users. How does Perceived Ease of Use (PEoU) affect the Perceived Usefulness (PU) (benefits), attitude, and satisfaction (s)? How does Perceived Usefulness (PU) (benefit) affect attitude (attitude) and satisfaction (s)? And how well the attitude (attitude) effect on satisfaction (s)?.

\section{Literature review}

\section{Disruptive innovation}

Disruptive innovation comes from the word disruptive which means to destroy, and innovation which means a new way or a new alternative. Literally means innovation that helps create new markets, disrupt or destroy existing markets, and ultimately replace the previous technology. Disruptive innovation develops a product or service in ways that the market does not expect, generally by creating different types of consumers in new markets and lowering prices in old markets.

The term Disruptive innovation began to be known when Clayton M. Christensen, a Business Professor from Harvard Business School, published a book titled The Innovator Dilemma in 1997. In the beginning Clayton M. Christensen called it disruptive technology, but as he developed he popularized the term Disruptive innovation to explain the above (Christensen, 1997).

At least according to Christensen (1997), Disruptive innovation must pay attention to the following: (1) Disruptive innovation is a process. (2) Disruptive innovation builds a different business model from the general model. (3) Not all disruptive innovation will succeed. (4) Disruptive innovation can be competed with competitors. 
Peer to Peer Lending Against Ease of...

\section{Financial technology (FinTech)}

FinTech is defined as a digital technology application platform for matters relating to financial intermediation (Aaron, et al, 2017). National Digital Research or NDRC defining FinTech as that term may be used to refer to innovations in the field of financial services or financial. It could also be financial innovation that is given a touch of modern technology.

FinTech is a financial industry that uses computing information technology centered on gadgets. FinTech is a financial innovation that changes the conventional system to the era of digital finance. Simply put, fintech is a variety of innovations that combine financial functions with technology. A fintech business actor who is often referred to as a start-up business actor provides an alternative solution to the public's need for financial services in Peer to Peer Lending financing.

\section{Peer to peer lending (P2P Lending)}

Peer to Peer Lending (P2P Lending) is a financial services system that brings together lenders with loan recipients in order to enter into a loan and loan agreement, through an electronic digital system using an internet connection. P2P Lending Service is an Indonesian legal entity provider that provides, manages, and operates information technology based lending and borrowing services. Loan Recipient (borrower) is a person and/or legal entity that has a debt due to a loan agreement to borrow money based on information technology. Lenders (Investors/lenders) are persons, legal entities, and/or business entities that have receivables due to loan service agreements to borrow money based on information technology.

The work scheme for Peer to Peer Lending can be seen at Figure 1:

Economica: Jurnal Ekonomi Islam - Volume 10, Nomor 2 (2019) https://journal.walisongo.ac.id/index.php/economica 
Figure 1. P2P Lending Work Scheme

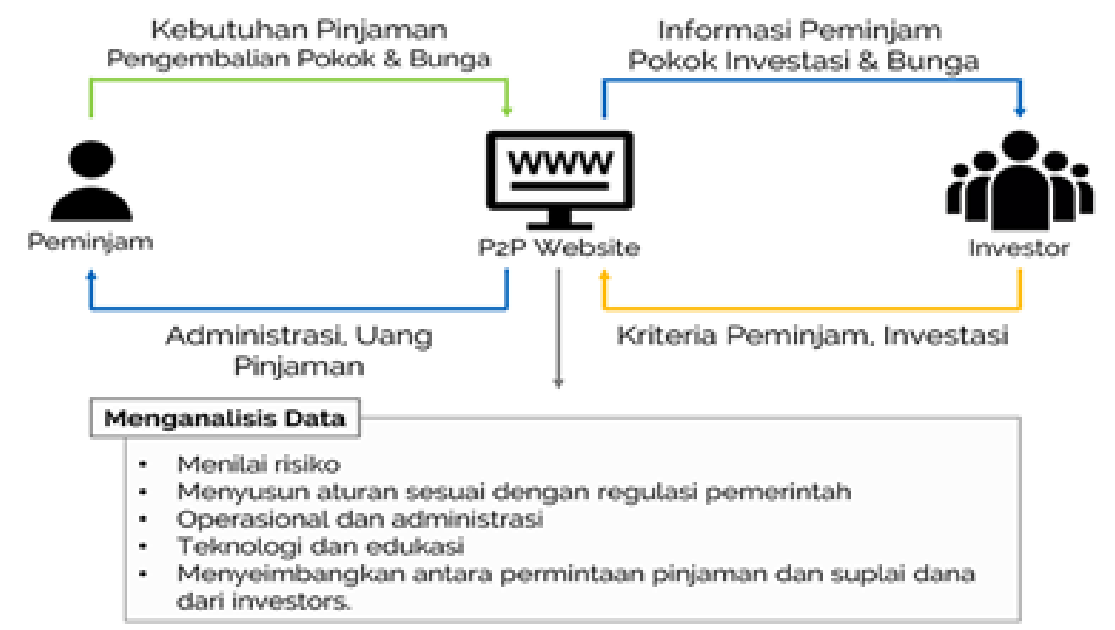

Procedure for submitting P2P Lending transactions, the borrower (borrower) needs to upload all the required documents, which are related to information related to the borrower (borrower). Documents that must be uploaded include financial statements within a certain period, identity, and reasons for borrowing money.

The borrower's loan status may be rejected or accepted, based on automated mechanisms through robot lending or manual eligibility. If it is refused, the borrower can correct everything that causes the rejection. If accepted, the loan interest rate will be determined and the borrower's submission will then be uploaded to the market place. Market place is a facility where lenders can see all available loan applications.

Then from the investor's side (lender) will be given access rights to be able to trace data related to the loan application that is available, including information about the loan application such as the borrower's financial history, the purpose of the loan, borrower's income, and so forth. It is intended that investors (lenders) are able to provide a feasibility analysis of the estimated investment to be made. 
If an investor (lender) meets the appropriate loan application and agrees to invest a number of funds, then the direct investment occurs when the investor (lender) makes a deposit according to the investor's investment objective (lender). The funds invested will return to investors (lenders) every month in the form of an installment whose value is the principal of the debt and are accompanied by interest that has been agreed in advance.

\section{Technology Acceptance Model (TAM)}

The Technology Acceptance Model (TAM) has been developed by Davis (1989). TAM is one of the most popular research models for predicting the use and acceptance of information systems and technology by individuals. TAM has been extensively studied and verified by various studies that examine individual technology acceptance behavior in a variety of different information systems.

In the TAM model, two factors namely usability (Perceived Usefulness/PU) and perceived ease of use (Perceived Ease of Use/PEoU) are relevant to the behavior of technology use, which was when the computer was booming. Davis defines Perceived Usefulness (PU) is something that is perceived as a subjective prospective user that using a special application system will improve the performance of work or life. Perceived ease of use (Perceived Ease of Use/PEOU) to identified as the degree to which prospective users expect ease the use of special application systems.

According to the TAM model, ease of use (Perceived Ease of Use/PEOU) and usefulness (Perceived usefulness/PU) are perceived is the most important determining factor of the actual use of the system (Actual System Use). Both of these factors are influenced by external variables. The main external factors that are usually manifested are social factors, cultural factors and political factors. Social factors include language, skills and facilitation conditions. Political factors mainly are the impact of the use of technology in politics and political crises. The attitude used is related to the user's evaluation 
of the desire to use certain information system applications. Behavioral intent is a measure of the likelihood of someone using the application (Davis et al., 1989).

The first TAM was developed by Davis (1986) based on the TRA (Theory of Reasoned Action) model. The TAM model based on the above explanation has 5 main constructs, namely: Perceived Usefulness (usability), Perceived Ease of Use (ease of use), and Attitude toward using technology (attitude), Behavioral intention to use (intention), and Actual Technology Use (use of technology) really. The concept illustrations are presented as Figure 2:

Figure 2. The Concept of Technology Acceptance Model (TAM)

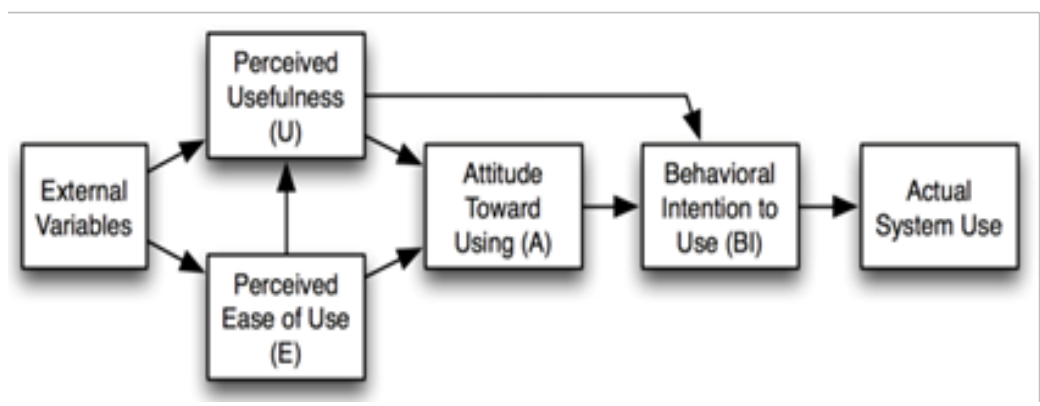

The first construct is Perceived Usefulness, hereinafter referred to as usability. Usability is defined as the extent to which a person believes that using a technology will improve the performance of his work (Davis, Jr., 1986). Previous research shows that usability is the most significant and important construct that influences attitudes, intensities and behavior (Jogiyanto, 2008). There are 6 indicators to measure the construct of usefulness, namely work is completed faster (work more quickly), improve performance (job performance), increase productivity (increase productivity), increase work effectiveness (effectiveness), facilitate work (makes job easier) and useful (useful) (Davis, Jr., 1986). 
The second construct is the Perceived Ease of Use, hereinafter referred to as ease of use. Ease of use is defined as the extent to which people believe that using a technology will be free of effort (Davis, Jr., 1986). This construct influences the construct of actual use, attitude, intention and use of technology. But the most significant is the effect on the construct of usability, while the effect on other constructs is not significant (Jogiyanto, 2008). There are 6 indicators to measure the construct of ease of use, namely the ease of the system to learn (easy of learn), the ease of the system to be controlled (controllable), the interaction with the stem that is clear and easy to understand (clear and understandable), the flexibility of interaction (flexibility), easy to skillfully use the system (easy to become skillful) and easy to use (Davis, 1989).

The third construct is Attitude toward Using Technology, hereinafter referred to as attitude. Attitudes can be defined as positive or negative feelings from someone if they have to do the behavior that will be determined (Davis, 1989). In the TAM model, attitude influences intention and is influenced by ease of use and usefulness. Jogiyanto also stated that in the research that had been done, some showed that attitude had a positive influence on intention, but some others also showed that attitude did not have a significant effect on intention. Therefore, there is a TAM study that does not include the construct of attitude in its model (Jogiyanto, 2008).

The fourth construct is Behavioral Intention to Use, hereinafter referred to as intention. Intention has an influence on the actual use of technology and is influenced by attitude and usability. There are 2 indicators to measure the construct of intentions, namely the use of a system to complete work (carrying out the task) and plans for future utilization (planned utilization in the future) (Gardner \& Amoroso).

The fifth construct is Actual Technology Use, hereinafter referred to as actual technology use or use. In TAM, the use of technology is actually equivalent to the term behavior (Behavior) in TRA but for use in a 
technological context. This construct is directly influenced by intention and usability. There are 3 indicators of the measurement of the construct of technology use, namely actual use, real frequency and user satisfaction.

The TAM model has been used by researchers around the world to understand the acceptance of various types of information systems. Zhou et al. has developed a new model based on TAM called the online shopping acceptance model (OSAM) to study online shopping behavior (Zhou et al., 2007).

Pavlou developed a model to predict e-commerce acceptance by adding trust in new variables and perceived risks (Paul A. Pavlou, 2003). According to a model developed by Pikkarainen to understand online banking acceptance in Finland, the perceived usefulness and information in online banking plays a very important role. Hsu and Chiu suggest a model that establishes that the pattern of acceptance and the role of internet self-efficacy play an important role in e-service adoption (Pikkarainen et al., 2004).

Ervasti \& Helaakoski have developed a model based on TAM and TPB to understand cellular service adoption which states that perceived benefits are the strongest factor in adoption (Ervasti \& Helaakoski, 2010). Muller Seitz et al. use the Technology Reception Model with security concerns to understand Radio Frequency Identification (RFID) reception (Müller-Seitz et al., 2009).

Based on TAM, Amin et al (2014) developed and tested FTAM in developing China after incorporating several constructs, such as social influence, innovation, job relevance, and self-efficacy, and relative superiority as an independent variable. In the Chinese context, both the relevance of work, innovation, social influence play an important role in influencing the intention to use ICT to enable products and services. In contrast, self-efficacy, which is considered an intrinsic motivational factor that can help local farmers to adopt technological solutions, cannot directly influence perceived ease of use. On the other hand social influences positively influence perceptions of ease of use. 
PU (Perceived Usefulness) and PEoU (Perceived Ease of Use) are factors that determine individual acceptance of technology. Both have a positive effect on attitude (Chuang et al., 2016). Attitude is an assessment (positive or negative) of individuals on new technology (Ajzen, 2002; Halilovic \& Cicic, 2011). Users believe that technology is easy to use (can start using without guidance) and is useful in solving their financial problems (can complete their tasks or work quickly), thus helping to improve user attitude.

But not so much research related to P2P Lending directly, especially in Indonesia. This is because P2P Lending has only been developing in Indonesia in the last 2 years, although globally it has been started since 2 decades. Moreover, the limitations of researchers in getting research that is almost similar. One of them in financial terms, Alex and Marlina (2017) has used the TAM model in receiving FinTech in Indonesia. TAM is used as a model to test how much influence the acceptance of FinTech sharia is represented by Paytren. The result was that FinTech had a disruption effect because it made it easier for users to carry out financial activities. FinTech provides business convenience for users. Therefore it becomes interesting when P2P Lending in the financial industry is then dissected by the TAM approach.

\section{Research hypothesis}

Based on the perception that P2P Lending products are products that are easy to use (Perceived Ease of Use/PEoU), the usefulness (Perceived Usefulness/PU) of P2P Lending products can be felt, so the first hypothesis is formulated as follows:

H1: Perceived Ease of Use (PEoU) has a positive effect on perceived usefulness (PU).

The TAM model previously explained that Perceived Usefulness (PU) is influenced by the perception of use (Perceived Ease of Use/PEoU). Therefore individuals who feel ease of use will feel that it has a use. Both of these will result in the attitude of the individual in the acceptance of the technology in 
question.(Davis, 1989, pp. 319-340) Based on the TAM model and the results of previous studies, the relationship between perception of use (Perceived Ease of Use/PEoU) and usefulness (Perceived Usefulness/PU) to attitudes (attitude) is formulated as follows:

H2: Perception of use (Perceived Ease of Use/PEOU) influential post itif against the attitude (attitude).

H3: Perceived usefulness (Perceived usefulness/PU) positive influence on the attitude (attitude).

\section{Methods}

\section{Types of research}

This type of research uses a field research/this study uses primary data because quantitative data were taken directly from respondents (online survey). The survey was chosen because the purpose of this study is to measure the perception of individual satisfaction in society over P2P Lending products and measure whether $\mathrm{P} 2 \mathrm{P}$ Lending provides business convenience for its users. This research is also a quantitative descriptive study. The variables in this study are Perceived Ease to Use (PEoU), Perceived Usefulness (PU), Attitude (A) and Satisfaction (S) which are implementations between Behavioral Intention to Use (BIU) and Actual Technology Use (Does FinTech Sharia Support Business Easiness?, 2017). After obtaining the data, the next step is to process the data using a statistical test and interpret the results (Cooper \& Schindler, 2011).

\section{Population and sample}

This research is used to see the perception of public satisfaction with P2P Lending products and the benefits in the form of business ease from the use of P2P Lending, the population in this study is all people who use P2P Lending products. Based on this population, samples that are considered to represent 
potential communities consist of entrepreneurs (businessman), state employees, private employees and students.

\section{Method of collecting data}

The method used in this study uses the online survey method which is directly answered by research respondents (Cooper \& Schindler, 2011). The questionnaire contains closed and open questions to measure the perception of P2P Lending users based on a 5 level Likert scale. The online survey model was chosen because of its ease of use, accuracy as well as providing an assessment of respondents' ability to apply technology, especially smartphone-based.

SEM with PLS only allows the model of relationships between variables that are recursive (unidirectional) only. In the structural model, which is also called the inner model, all latent variables are related to one another based on substance theory. Latent variables are divided into two, namely exogenous and endogenous. Exogenous latent variables are causal variables or variables without preceding other variables with arrows going to other variables (endogenous latent variables). So the construct in this study is as follows:

Figure 3. Research modeling construct

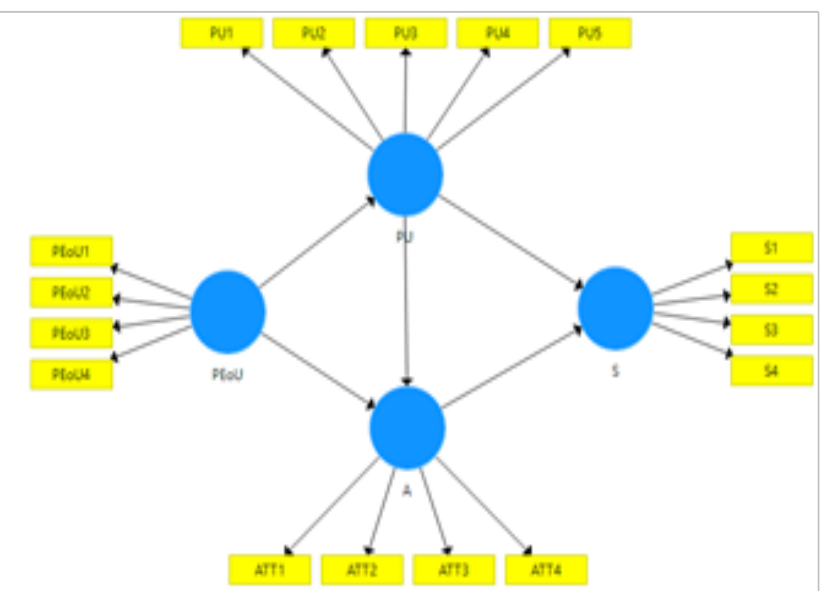

Economica: Jurnal Ekonomi Islam - Volume 10, Nomor 2 (2019) https://journal.walisongo.ac.id/index.php/economica 


\section{Result and discussion}

Based on the SEM-PLS calculation, it is known that the significance value of the influence between the perception of use (Perceived Ease of Use) denoted by PEoU on the perception of usefulness (Perceived Usefulness) denoted by PU, has a t value of 14.961 with a $p$ value of 0.000 . The value of $p$ value is smaller than $\alpha$ so it can be concluded that the perception of use (Perceived Ease of Use) has a significant positive effect on usability (Perceived Ease of Use). This means that the greater the perceived value of ease of use based on empirical experience will affect the usefulness of the application, in this case P2P Lending. This is in line with the results conducted (Chuang et al., 2016; Davis et al., 1989; Mathieson, 1991; Hu et al., 1999; Alex et al., 2017).

The effect of use (Perceived Ease of Use) in this study is the user experience in operating applications, namely the P2P L ending platform installed on a smartphone. This variable identifies related to ease of use. The results of the answers to the questions in this variable are presented as table 8:

Table 8. Summary of Usage Perception Answers

\begin{tabular}{ll}
\hline Item Questions & Average Score \\
\hline Ease of Interaction & 3.76 \\
Ease of Access & 3.73 \\
Saving time & 3.86 \\
Use as intended & 3.84 \\
\hline
\end{tabular}

Based on the table 8 results, it is known that each question has a score above 3. This means that the average respondent answers questions related to the question items that are indicators of the Perceived Ease of Use variable, agreeing that the experience using the P2P Lending application is indeed easy. 
The ease is seen from the interface that is easy and simple, so that users are indeed facilitated in exploring the menu in the application.

Influence the perception of the use of Perceived Ease of Use (PEOU) to attitude has a value of $t$ count equal to 2,379 with $p$ value 0.018 . P value less than the $\alpha$ so that it can be concluded that the perception of the use of (Perceived Ease of Use) significant positive effect on the attitude (attitude). This means that the greater the perceived value of ease of use based on empirical experience will affect individual attitudes in usage behavior.

From respondent data related to the response variable question the attitude, obtained the following information as table 9:

Table 9. Summary of Attitude Answers

\begin{tabular}{ll}
\hline Item Questions & Average Score \\
\hline Transaction Guarantee & 3.92 \\
Increased Target Achievement & 3.89 \\
Financial Fulfillment & 3.84 \\
Long-term Use & 3.87 \\
\hline
\end{tabular}

Based on the table 9 results, it is known that each question has a score above 3. Its mean average respondent answered questions related items are indicators of attitude variables (attitude) is agreed that P2P Lending well received by users.

Influence the perception of the usefulness (Perceived usefulness) of the attitude has a value of $t$ count equal to 2,212 with $p$ value of 0.027 . P value less than $\alpha$ so that it can be concluded that the perceived usefulness (Perceived usefulness) significant positive effect on the attitude. This means that the greater the value of perceived usefulness or benefits obtained by users will increase the intensity of individual attitudes in usage behavior.

Economica: Jurnal Ekonomi Islam - Volume 10, Nomor 2 (2019) 
Cita Sary Dja'akum

The following is a summary of the respondents' answers regarding the perception of usefulness (Perceived Usefulness):

Table 10. Summary of Responses to Perception of Use

\begin{tabular}{ll}
\hline Item Questions & Average Score \\
\hline Resolution of Financial Problems & 3.63 \\
Business Improvement & 3.68 \\
Management and Planning & 3.86 \\
Improved Performance & 3.60 \\
Effective and Efficient & 3.63 \\
\hline
\end{tabular}

Based on the table 10 results, it is known that each question has a score above 3. This means that the average respondent answered questions related items being usefulness perception variables indicator is agreed that P2P Lending to have an impact in the form of benefits of use, so powerful towards users. P2P Lending is considered capable of providing solutions to financial difficulties for users of the P2P L Lending platform.

Influence the perception of the usefulness (Perceived usefulness) to satisfaction has a value of $t$ se large 3.028 with $p$ value of 0.003 . P value less than $\alpha$ so that it can be concluded that the perceived usefulness (Perceived usefulness) significant positive effect on satisfaction (satisfaction). This means that the greater the perceived value of usability or benefits obtained by the user, it will increase individual satisfaction in the use of the tool/instrument/application.

Following are the summary results of the respondents' answers related to perceived usefulness (satisfaction): 
Peer to Peer Lending Against Ease of...

Table 11. Summary of Satisfaction Perception Answers

\begin{tabular}{ll}
\hline Item Questions & Average Score \\
\hline User Experience Satisfaction & 3.18 \\
Service Satisfaction & 3.18 \\
Addiction (loyalty) & 3.63 \\
Use Comfort & 3.36 \\
\hline
\end{tabular}

Based on the table 11, it is known that the mean score above 3 , so that the perception of use (Perceived Usefulness) variable has a positive effect on satisfaction. It means that the aspect of experience using the P2P Lending platform application is satisfied with the facilities provided.

Influence of attitude (attitude) to the satisfaction has a t value of 3.091 with $p$ value of 0.002 . P value less than $\alpha$ so that it can be concluded that the attitude has a significant positive effect on satisfaction. This means that if the user's attitude shows a positive thing, such as increasing the intensity of use it will increase individual satisfaction in the use of the tool.

\section{Conclusion}

Technological progress is a necessity. P2P Lending is a form of financial innovation based on technology or known as FinTech (Financial Technology). In this study, researchers wanted to find out whether the impact of FinTech through its P2P Lending product was able to provide convenience in business ?. Based on TAM (Technology Acceptance Model) modeling, constructs consist of PEoU (Perveived Ease Of Use) or perceived use, PU (Perceived Usefulness) or perceived use, attitude and satisfaction. This satisfaction is the meeting point where the respondent responds whether the P2P Lending platform provides benefits for the businesses that are doing the respondent's business.

Economica: Jurnal Ekonomi Islam - Volume 10, Nomor 2 (2019) 
Cita Sary Dja'akum

Based on statistical modeling through SEM (Structural Equation Modeling), it shows that PEoU is positively related to PU. This shows that the easier a product is to use in a process, the higher the perceived usefulness of the user of the product.

Then when the product is easy to use (PEoU), the usefulness (PU) of the product, in this case, P2P Lending can be felt. Both are constructs forming attitude (attitude). This means that individuals have the belief that P2P Lending is easy to use (practical) and useful in solving their financial problems (effectively and efficiently), so that the user's attitude towards P2P Lending services increases.

Then the construct PEoU, PU and attitude have a positive effect on satisfaction (satisfaction) of individuals who use P2P Lending. Satisfaction becomes a benchmark in assessing the utility of P2P Lending products. User perceptions of ease (PEoU), usability (PU), and positive feelings (attitude) on P2P Lending products encourage the creation of a feeling of satisfaction with what has been used.

In general the P2P Lending platform offers various conveniences in the millennial era as it is today. There are many advantages that can be obtained in using the P2P Lending platform. But that does not mean this system is ideal. This means that there are still some improvements that must be done. Such as fraud minimization, increased supervision by $0 \mathrm{JK}$, increased digital financial literacy and prosecution of incidents of persecution and intimidation in installment billing.

Limitations in this study are the number of respondents still below 100 people, respondents still revolve around the user from the borrower side. This research will be more comprehensive if the number of respondents is increased even more, combining borrowers, lenders and P2P Lending companies so that the discussion and analysis will be sharper and deeper. 
Peer to Peer Lending Against Ease of...

\section{References}

Adamson, I., \& Shine, J. (2003). Extending the new technology acceptance model to measure the end user information systems satisfaction in a mandatory environment: A Bank's Treasury. Technology Analysis and Strategic Management.

Ajzen, I. (2002). Perceived behavioral control, self-efficacy, locus of control, and the theory of planned behavior. Journal of Applied Social Psychology.

Al-hawari, M. A., \& Mouakket, S. (2010). The influence of technology acceptance model (TAM) factors on students' e-satisfaction and eretention within the context of UAE e-learning. Education, Business and Society: Contemporary Middle Eastern Issues.

Alt, R., \& Puschmann, T. (2012). The rise of customer-oriented banking Electronic markets are paving the way for change in the financial industry. Electronic Markets.

Baron, R. M., \& Kenny, D. A. (1986). The Moderator-Mediator Variable Distinction in Social Psychological Research. Conceptual, Strategic, and Statistical Considerations. Journal of Personality and Social Psychology.

Çetin, F. (2011). The effects of the organizational psychological capital on the attitudes of commitment and satisfaction: A public sample in Turkey. European Journal of Social Sciences.

Chau, P. Y. K., \& Hu, P. J. H. (2002). Investigating healthcare professionals' decisions to accept telemedicine technology: An empirical test of competing theories. Information and Management.

Chen, M.-C., Chen, S.-S., Yeh, H.-M., \& Tsaur, W.-G. (2016). The Key Factors Influencing Internet Finances Services Satisfaction: An Empirical Study in Taiwan. American Journal of Industrial and Business Management.

Christensen, C. M. (1997). Innovator's Dilemma. In Business.

Chuang, L.-M., Liu, C.-C., \& Kao, H.-K. (2016). The Adoption of Fintech Service: TAM perspective. International Journal of Management and Administrative Sciences (IJMAS.

Cooper, D. R., \& Schindler, P. S. (2011). Business Research Methods Eleventh Edition. In McGraw Hill.

Economica: Jurnal Ekonomi Islam - Volume 10, Nomor 2 (2019) 
Davis, Jr., F. D. (1986). A technology acceptance model for empirically testing new end-user information systems: Theory and results [Dissertation]. Doctoral Dissertation, Massachusetts Institute of Technology.

Davis, F. D. (1989). Perceived usefulness, perceived ease of use, and user acceptance of information technology. MIS Quarterly: Management Information Systems.

Davis, F. D., Bagozzi, R. P., \& Warshaw, P. R. (1989). User Acceptance of Computer Technology: A Comparison of Two Theoretical Models. Management Science.

Does FinTech Sharia Support Business Easiness? (At the Sharia Economic and Financial Research Forum (FREKS XVI)). (2017).

Ervasti, M., \& Helaakoski, H. (2010). Case study of application-based mobile service acceptance and development in Finland. International Journal of Information Technology and Management.

Gardner, C., \& Amoroso, D. L. (2004). Development of an instrument to measure the acceptance of internet technology by consumers. Proceedings of the Hawaii International Conference on System Sciences.

Garvey, K., Zhang, B., Ralston, D., Ying, K., Yi Chen, H., Buckingham, E., Katiforis, Y., \& Deer, L. (2017). Cultivating Growth: The 2nd Asia Pasific Region Alternative Finance Industry Report.

Hair, J. F., Ringle, C. M., \& Sarstedt, M. (2011). PLS-SEM: Indeed, a silver bullet. Journal of Marketing Theory and Practice.

Hair, J. F., Sarstedt, M., Ringle, C. M., \& Mena, J. A. (2012). An assessment of the use of partial least squares structural equation modeling in marketing research. Journal of the Academy of Marketing Science.

Jogiyanto. (2008). Sistem Informasi Keperilakuan. ANDI.

Jung, Y. H., Kim, G., \& Lee, C. C. (2015). Factors Influencing User Satisfaction and Continuous Usage Intention on Mobile Credit Card: Based on Innovation Diffusion Theory and Post Acceptance Model. The Journal of Society for E-Business Studies.

Mariani, M. G., Curcuruto, M., \& Gaetani, I. (2013). Training opportunities, technology acceptance and job satisfaction: A study of Italian organizations. Journal of Workplace Learning. 
Mather, D., Caputi, P., \& Jayasuriya, R. (2002). Is the technology acceptance model a valid model of user satisfaction of information technology in environments where usage is mandatory? Enabling Organisations and Society through Information Systems.

Mathieson, K. (1991). Predicting user intentions: Comparing the technology acceptance model with the theory of planned behavior. Information Systems Research.

Monecke, A., \& Leisch, F. (2012). SemPLS: Structural equation modeling using partial least squares. Journal of Statistical Software.

Müller-Seitz, G., Dautzenberg, K., Creusen, U., \& Stromereder, C. (2009). Customer acceptance of RFID technology: Evidence from the German electronic retail sector. Journal of Retailing and Consumer Services.

Mustafa, Z. (2009). Mengurai Variabel hingga Instrumentasi. Graha Ilmu.

Nam, K., Lee, Z., \& Lee, B. G. (2016). How internet has reshaped the user experience of banking service? KSII Transactions on Internet and Information Systems, 10(2), 684-702.

Paul A. Pavlou. (2003). Consumer Acceptance of Electronic Commerce: Integrating Trust and Risk with the Technology Acceptance Model. International Journal of Electronic Commerce.

Pikkarainen, T., Pikkarainen, K., Karjaluoto, H., \& Pahnila, S. (2004). Consumer acceptance of online banking: An extension of the technology acceptance model. In Internet Research.

Şahin, A., Zehir, C., \& Kitapçi, H. (2011). The effects of brand experiences, trust and satisfaction on building brand loyalty; an empirical research on global brands. Procedia - Social and Behavioral Sciences.

Tenenhaus, M., Vinzi, V. E., Chatelin, Y. M., \& Lauro, C. (2005). PLS path modeling. Computational Statistics and Data Analysis.

Wixom, B. H., \& Todd, P. A. (2005). A theoretical integration of user satisfaction and technology acceptance. Information Systems Research.

Zhou, L., Dai, L., \& Zhang, D. (2007). Online Shopping Acceptance Model - a Critical Survey of Consumer Factors in Online Shopping. Journal of Electronic Commerce Research. 
Cita Sary Dja'akum 